\title{
Correspondence
}

\section{MOOCs taken by educated few}

Massive open online courses (MOOCs) have been hailed as an educational revolution that has the potential to override borders, race, gender, class and income (see go.nature.com/ hanoau). However, a survey of active MOOC users in more than 200 countries and territories has revealed that most students on these courses are already well educated - and that they are predominantly young males seeking to advance their careers.

Our data are drawn from 34,779 responses to a July 2013 survey by the University of Pennsylvania, USA, of participants in 32 course sessions of the online education service Coursera (see https://www. coursera.org/penn). We found that $83 \%$ of surveyed students already had a two- or four-year post-secondary degree (see 'MOOCs are not reaching the disadvantaged', red bars), with $44.2 \%$ reporting education beyond a bachelor's degree (see go.nature.com/cvjp8u).

Furthermore, the prior educational standard among MOOC students across the world far exceeds that of the general population in their own countries (see figure, blue bars; source: www.barrolee.com).

This educational disparity is particularly stark in Brazil, Russia, India, China and South Africa, all of which are prime candidates for MOOC education. In those countries, almost $80 \%$ of MOOC students come from the wealthiest and most well-educated $6 \%$ of the population.

We found that men account for $56.9 \%$ of all MOOC students (and 64\% in countries outside the Organisation for Economic Co-operation and Development; OECD). Also, almost 70\% of MOOC students are already in employment (these data are not shown).

Far from realizing the high

\section{MOOCS ARE NOT REACHING THE DISADVANTAGED}

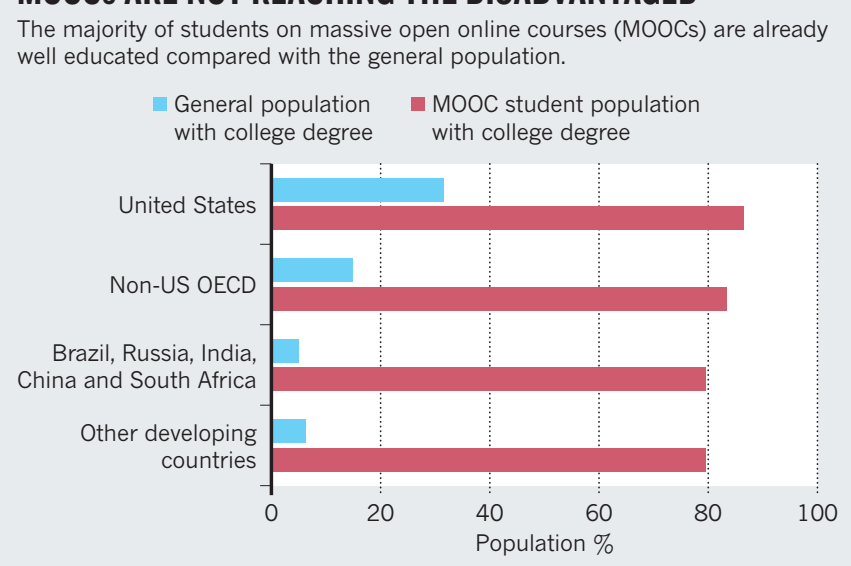

ideals of their advocates, MOOCs seem to be reinforcing the advantages of the 'haves' rather than educating the 'havenots. Better access to technology and improved basic education are needed worldwide before MOOCs can genuinely live up to their promise.

Ezekiel J. Emanuel University of Pennsylvania, Philadelphia, USA. vp-global@upenn.edu

${ }^{*}$ On behalf of 6 co-signatories (see go.nature.com/8lqpa5 for a full list).

\section{Backing up forensic DNA evidence}

Pakistan's leading Islamic guidance body, the Council of Islamic Ideology, recently declared that DNA profiling is inadequate as primary evidence for rape crimes and should be supported by other forms of evidence laid out in Islamic law - for example, a confession, or confirmation from four adult male eyewitnesses (see go.nature.com/myllda).

The council's ruling is based on the inability of DNA testing to distinguish between forced and consensual sex. We hope, however, that it will be sufficiently flexible to accommodate DNA testing when it could be decisive - for example, in cases of child abuse, when geographical location precludes the presence of eyewitnesses, or when the rape victim is murdered.

Collaboration between forensic scientists and religious scholars would foster such flexibility by improving mutual understanding and facilitating more informed decisionmaking.

Rape crimes in Pakistan are currently not accountable to civil law, but are judged according to the 1979 Hudood Ordinance, which faces mounting criticism from human-rights organizations and moderate sectors of civil society. By diminishing the importance of DNA testing, the council seems to be endorsing the stance of the Hudood Ordinance. Mushtaq Hussain, Ammara Mushtaq Dow University of Health Sciences, Karachi, Pakistan.

mushtaq.hussain@duhs.edu.pk

\section{Smarten up on intelligence genetics}

You write that " $50 \%$ of variability in intelligence seems to be inherited" (Nature 502, 26-28; 2013). This figure is derived from quantitative genetic studies that do not seem to be founded on sound scientific reasoning.

It is unlikely that quantitative genetics can be reasonably applied to mental traits in humans. There can be no single value, or even range of values, for the heritability of intelligence, because environmental differences vary vastly between populations - consequently, published values for the heritability of intelligence range between $0 \%$ and $100 \%$.

Indeed, the heritability of intelligence has little to do with its malleability — so why estimate it in the first place? The whole idea seems brain-dead to me.

M. Velden Department of Psychology, University of Mainz, Germany.

\section{Database differences not citation errors}

Differences in citation records across international databases reflect variations in their coverage of the scientific literature, rather than inaccuracies (D. Shotton Nature 502, 295-297; 2013).

Google Scholar, for example, indicates the number of citations that have appeared in almost any online scientific material. Thomson Reuters' Web of Science records only the number of citations in selected highimpact journals. Both numbers are accurate on the basis of each source's indexing criteria, so each should be interpreted individually.

Mohammad H. Nowroozzadeh Poostchi Eye Research Centre, Shiraz University of Medical Sciences, Shiraz, Iran. norozzadeh@gmail.com

\section{CONTRIBUTIONS}

Correspondence may be sent to correspondence@ nature.com after consulting the author guidelines at http://go.nature.com/ cmchno. Alternatively, readers may comment online: www.nature.com/ nature. 